Article

\title{
Prediction of Sugarcane Yield Based on NDVI and Concentration of Leaf-Tissue Nutrients in Fields Managed with Straw Removal
}

\author{
Izaias Pinheiro Lisboa ${ }^{\circledR}$, Júnior Melo Damian*®D, Maurício Roberto Cherubin ${ }^{\circledR}$, \\ Pedro Paulo Silva Barros ${ }^{\mathbb{D}}$, Peterson Ricardo Fiorio, Carlos Clemente Cerri and \\ Carlos Eduardo Pellegrino Cerri \\ "Luiz de Queiroz" College of Agriculture, University of São Paulo, 11 Pádua Dias Avenue, \\ Piracicaba, SP 13418-900, Brazil; iplisboaa@gmail.com (I.P.L.); cherubin@usp.br (M.R.C.); \\ pedropaulo@usp.br (P.P.S.B.); fiorio@usp.br (P.R.F.); cerri@cena.usp.br (C.C.C.); cepcerri@usp.br (C.E.P.C.) \\ * Correspondence: damianjrm@usp.br; Tel.: +55-559-996-90524
}

Received: 29 July 2018; Accepted: 13 September 2018; Published: 19 September 2018

\begin{abstract}
The total or partial removal of sugarcane (Saccharum spp. L.) straw for bioenergy production may deplete soil quality and consequently affect negatively crop yield. Plants with lower yield potential may present lower concentration of leaf-tissue nutrients, which in turn changes light reflectance of canopy in different wavelengths. Therefore, vegetation indexes, such as the normalized difference vegetation index (NDVI) associated with concentration of leaf-tissue nutrients could be a useful tool for monitoring potential sugarcane yield changes under straw management. Two sites in São Paulo state, Brazil were utilized to evaluate the potential of NDVI for monitoring sugarcane yield changes imposed by different straw removal rates. The treatments were established with $0 \%, 25 \%$, $50 \%$, and $100 \%$ straw removal. The data used for the NDVI calculation was obtained using satellite images (CBERS-4) and hyperspectral sensor (FieldSpec Spectroradiometer, Malvern Panalytical, Almelo, Netherlands). Besides sugarcane yield, the concentration of the leaf-tissue nutrients (N, P, K, $\mathrm{Ca}$, and S) were also determined. The NDVI efficiently predicted sugarcane yield under different rates of straw removal, with the highest performance achieved with NDVI derived from satellite images than hyperspectral sensor. In addition, leaf-tissue $\mathrm{N}$ and $\mathrm{P}$ concentrations were also important parameters to compose the prediction models of sugarcane yield. A prediction model approach based on data of NDVI and leaf-tissue nutrient concentrations may help the Brazilian sugarcane sector to monitor crop yield changes in areas intensively managed for bioenergy production.
\end{abstract}

Keywords: crop residue management; remote sensing; satellite images; hyperspectral sensor; vegetation index; yield monitoring

\section{Introduction}

Brazil is the largest sugarcane producer in the world, representing $40 \%$ of global production [1] Sugarcane area extends for approximately 9 million ha, with an ethanol production at around 27 billion liters and about 40 million tonnes of sugar [2]. Although Brazil is a major player in the global biofuel market, growing internal and external demands have been stimulated an increase in ethanol production. Considering the current global production of 98.6 billion liters [3], it will be necessary to double ethanol production to meet the estimated global demand of 200 billion liters in 2021 [4]. In addition, bioelectricity represents an important proportion of the revenues in the industry, and it is projected that about $17 \%$ of the domestic electric energy production in Brazil will be provided by sugarcane biomass by 2023 [5]. 
An alternative to increase bioenergy production, without expanding area, is to use lignocellulosic raw materials, such as bagasse and straw. In this process, crop residues, rich in carbohydrates, are converted into simple sugars using enzymatic hydrolysis, followed by yeast fermentation to produce ethanol, or crop residues are burnt to generate bioelectricity [6].

More recently, sugarcane straw has been considered as an alternative raw material to address the increasing demand for bioenergy production [7]. Since adoption of mechanized harvesting of sugarcane, about 10 to $20 \mathrm{Mg} \mathrm{ha}^{-1}$ (as dry mass) remains on the field annually [8]. However, integral or partially straw retention on the soil surface is essential to support several soil functions [9,10], such as thermal regulation [11], control of soil compaction [12], water retention [13], carbon storage [14], nutrient cycling [15], biological activities [16], and control of erosion [17]. Consequently, changes in soil quality can affect, directly or indirectly, crop production [14,18,19]. Therefore, monitoring the yield of sugarcane could be a strategy to evaluate the effects of varying the amount of straw in the soil-plant system.

Crop yield can be monitored by vegetation indexes. Indeed, Tucker et al. [20] reported that up to $64 \%$ of the grain yield variation was explained by spectral data. The applications of NDVI has been broadly increased, not only because NDVI can be derived from data of either hyperspectral sensors or satellite images [21], but also because it is closely correlated with yield of different crops [22], such as maize (Zea mays L.) [23], soybean (Glycine max L.) [24], and sugarcane [25]. Additionally, deficiency and excess of nutrients in the leaves can be diagnosed through spectral responses obtained by sensors and, consequently, by vegetation indexes (e.g., NDVI) [26]). The variation in the concentration of nutrients in the leaves indicates physiological stress, which can be caused by diverse limiting factors that occurring in the production environment [27].

Although NDVI has been used for different purposes, as previously stated, in our knowledge, there are no studies in the literature in which NDVI and concentration of leaf-tissue nutrients under sugarcane straw removal management were used to develop predictive models for stalk yield. Thus, the following hypotheses were established: (i) the NDVI and concentration of leaf-tissue nutrients are efficient parameters to predict sugarcane yield under different straw removal rates; (ii) the NDVI obtained using data from satellite images or hyperspectral sensors have similar performance for predicting sugarcane yield; and (iii) the nutritional status of the crop (evaluated by the leaf-tissue nutrient concentrations) is affected by the different straw removal rates. To test the hypotheses, a study was conducted in areas managed with straw removal in southeastern Brazil to predict sugarcane yield based on NDVI and plant nutritional status. In addition, the efficiency of the NDVI data for predicting sugarcane yield, obtained using remote sensing imagery from various platforms, was compared.

\section{Materials and Methods}

\subsection{Study Sites}

The field study was conducted at two sites in southeastern Brazil, which represents the largest sugarcane-producing region of the country. These areas are located in São Paulo state, near to Capivari, at the Bom Retiro mill (Area 1) (Lat. $22^{\circ} 59^{\prime} 42^{\prime \prime} \mathrm{S}$; Long. $47^{\circ} 30^{\prime} 34^{\prime \prime} \mathrm{W}$ ) and Valparaiso, at the Univalem

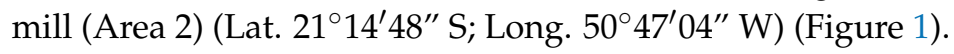

Soil is classified as Rhodic Kandiudox [28] with a sandy clay loam texture in Area 1, whereas in Area 2, the soil is classified as Kanhaplic Haplustults [28] with a sandy loam texture.

The regional climate for the Area 1 is humid subtropical-Cwa type (Köppen classification) characterized by dry winters and hot summers, with a mean annual temperature of $21.8^{\circ} \mathrm{C}$ and annual precipitation of $1289 \mathrm{~mm}$ (Figure 2A). In the Area 2, the climate is tropical-Aw type, characterized by dry winters, with a mean annual temperature of $23.4^{\circ} \mathrm{C}$ and annual precipitation of $1241 \mathrm{~mm}$ (Figure 2B). Rainfall at both sites is concentrated in the spring and summer (October to April), while the dry season is in the autumn and winter (May to September). 


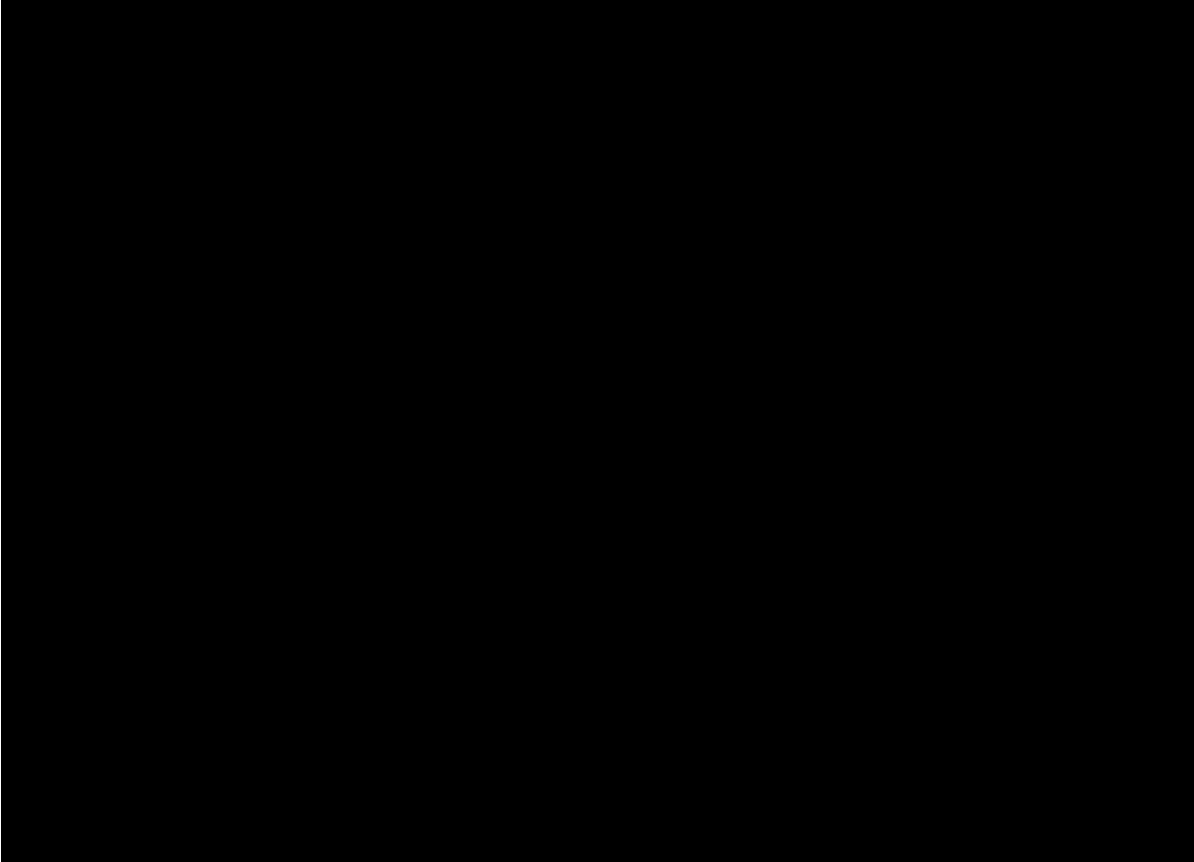

Figure 1. Geographical location of the experimental areas used in the study.



Figure 2. Mean monthly temperatures (maximum, mean, and minimum) $\left({ }^{\circ} \mathrm{C}\right)$ and monthly precipitation ( $\mathrm{mm}$ ) in Area 1 (Capivari, SP) (A) and Area 2 (Valparaiso, SP) (B) from 1 December 2015 to 31 December 2016. Sources: CEPAGRI [29] and ESALQ [30]. 


\subsection{Experimental Design}

Within each site, sugarcane was planted in 15 February 2013, using the varieties CTC 14 and RB 867515 in Area 1 and Area 2, respectively. These varieties are broadly cultivated in this sugarcane-producing region of Brazil. Before the experiment was installed, the areas were sampled in order to obtain a chemical and physical characterization of the soils (Table 1), as previously presented by Satiro et al. [12].

Table 1. Initial characterization of the soils in the experimental areas.

\begin{tabular}{|c|c|c|c|c|c|c|c|c|c|}
\hline \multirow{2}{*}{$\begin{array}{l}\text { Soil } \\
\text { Layer } \\
\text { (cm) }\end{array}$} & $\mathrm{pH}$ & $\mathrm{C}$ & $\mathbf{P}$ & $\mathbf{K}$ & $\mathrm{Ca}$ & Mg & $\begin{array}{c}\text { Base } \\
\text { Saturation }\end{array}$ & $\begin{array}{c}\text { Al } \\
\text { Saturation }\end{array}$ & Clay \\
\hline & $\mathrm{H}_{2} \mathrm{O}$ & $\mathrm{g} \mathrm{kg}^{-1}$ & $\mathrm{mg} \mathrm{dm}^{-3}$ & \multicolumn{3}{|c|}{$\mathrm{mmol}_{\mathrm{c}} \mathrm{dm}^{-3}$} & \multicolumn{3}{|c|}{$\%$} \\
\hline & \multicolumn{9}{|c|}{ Area 1 (Bom Retiro) } \\
\hline $0-10$ & 5.2 & 11.3 & 29.3 & 9.3 & 26.1 & 7.7 & 68.8 & 0.8 & 33 \\
\hline $10-20$ & 4.8 & 11.0 & 24.9 & 5.1 & 19.0 & 5.9 & 54.7 & 3.5 & 33 \\
\hline \multirow[t]{2}{*}{$20-30$} & 4.5 & 9.4 & 22.1 & 3.3 & 12.5 & 2.95 & 36.8 & 4.2 & 34 \\
\hline & \multicolumn{9}{|c|}{ Area 2 (Univalem) } \\
\hline $0-10$ & 5.2 & 6.1 & 17.4 & 3.3 & 9.3 & 2.9 & 51.1 & 2.4 & 11 \\
\hline $10-20$ & 4.8 & 5.5 & 14.1 & 2.6 & 4.8 & 1.5 & 34.8 & 5.6 & 11 \\
\hline $20-30$ & 4.5 & 4.9 & 12.7 & 2.1 & 3.6 & 1.0 & 27.5 & 7.4 & 12 \\
\hline
\end{tabular}

The cane plant (i.e., first cycle) was cultivated for 20 months, thereafter the harvested was performed in 15 October 2014 and the experiments with different rates of straw removal were established. After 14 months, in 17 December 2015, the areas were harvested again and similar experiments were conducted. Leaf sampling and sensor data collection were done during the second sugarcane ratoon season (Figure 3). The experiments were mechanically established with harvester, which was set up with different angular velocities on the primary extractor fan while the secondary extractor fan was switched on or off to remove different quantities of sugarcane straw. Details on how extractors were set up are described in Lisboa et al. [7].

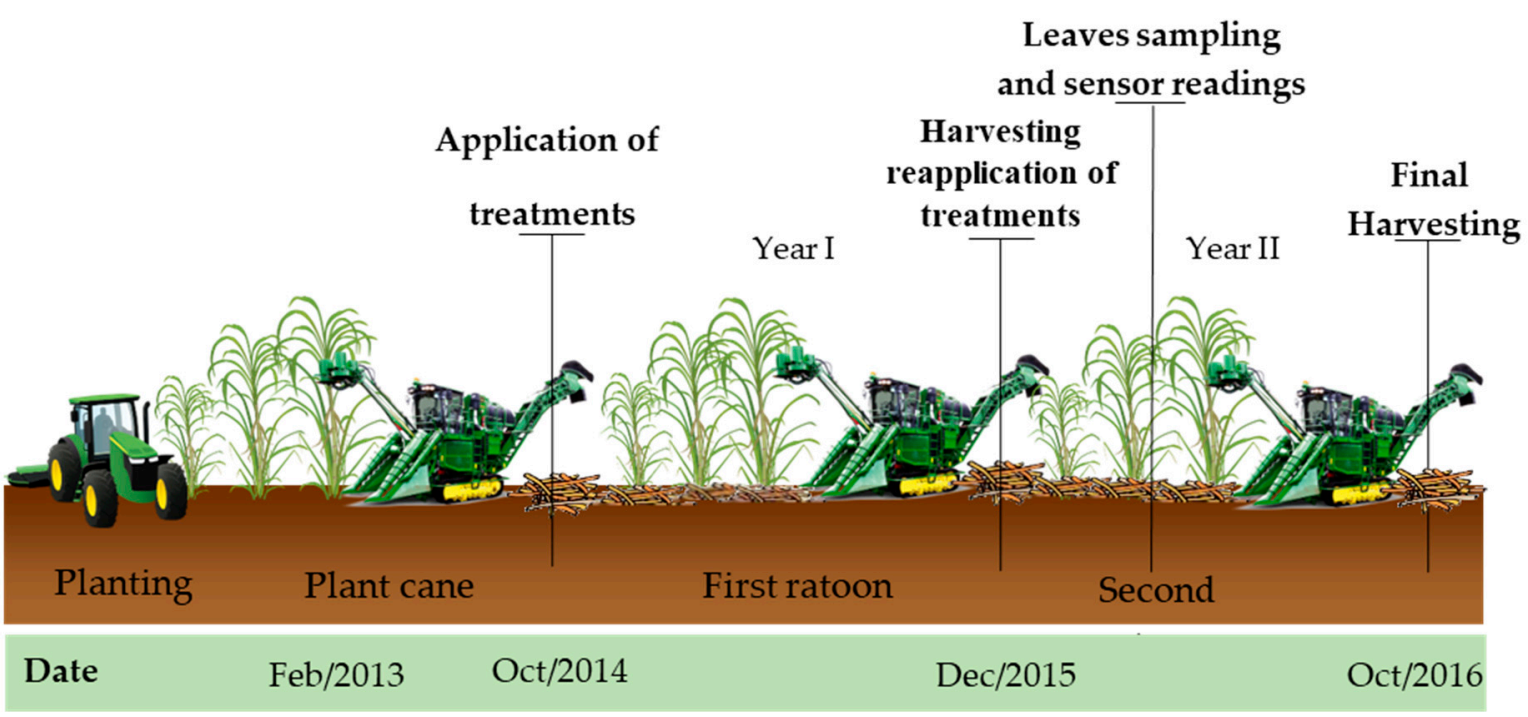

Figure 3. Timeline of the experiments establishment (at harvesting) and conduction over two years in southeast of Brazil. Source: adapted from Lisboa et al. [19].

The experimental design was randomized blocks with four treatments (i.e., straw removal rates), and four replications (four plots of $\sim 50 \times 25 \mathrm{~m}$ ). Initially, the aim was to remove the amount of 
straw proportional to $0 \%, 25 \%, 50 \%$, and $100 \%$ of the straw yield in each area. However, under field conditions, the exact proportion was hard to be achieved, but the removal rates were very close to those proposed (Table 2).

Table 2. Amount of sugarcane straw left on soil surface after each treatment in the first and second years in each experimental area.

\begin{tabular}{|c|c|c|c|c|}
\hline \multirow{2}{*}{ Straw Removal Rate (\%) } & \multicolumn{2}{|c|}{ Area 1 (Bom Retiro) } & \multicolumn{2}{|c|}{ Area 2 (Univalem) } \\
\hline & Year I & Year II & Year I & Year II \\
\hline & \multicolumn{4}{|c|}{ Amount of straw left on the soil surface $\left(\mathrm{Mg} \mathrm{ha}^{-1}\right) \#$} \\
\hline 100 & $0.0 \pm 0.0$ & $0.0 \pm 0.0$ & $0.0 \pm 0.0$ & $0.0 \pm 0.0$ \\
\hline 50 & $8.7 \pm 0.9$ & $5.5 \pm 1.0$ & $10.2 \pm 0.9$ & $6.8 \pm 0.4$ \\
\hline 25 & $15.1 \pm 1.5$ & $10.5 \pm 0.1$ & $12.5 \pm 0.9$ & $11.6 \pm 0.5$ \\
\hline 0 & $18.9 \pm 1.6$ & $13.6 \pm 2.0$ & $16.4 \pm 1.4$ & $13.7 \pm 1.1$ \\
\hline
\end{tabular}

${ }^{\#}$ Dry mass; Source: adapted from Lisboa et al. [19].

At the start of each experiment period, the sugarcane straw was sampled to determine its elemental composition (Table 3).

Table 3. Carbon (C) and macronutrient (nitrogen $-\mathrm{N}$, phosphorus $-\mathrm{P}$, potassium $-\mathrm{K}$, calcium $-\mathrm{Ca}$, magnesium $-\mathrm{Mg}$, sulphur-S) content of the sugarcane straw used in each experiment.

\begin{tabular}{ccccccccc}
\hline \multirow{2}{*}{ Sites } & $\mathbf{C}$ & $\mathbf{N}$ & $\mathbf{P}$ & $\mathbf{K}$ & $\mathbf{C a}$ & $\mathbf{M g}$ & $\mathbf{S}$ & C:N Ratio \\
\cline { 2 - 9 } & \multicolumn{7}{c}{$\mathbf{g ~ k g}^{-\mathbf{1}}$} \\
\hline Area 1 I (Bom Retiro) & 479 & 2.58 & 0.39 & 1.66 & 1.96 & 1.38 & 0.45 & 177 \\
Area 1 II (Bom Retiro) & 470 & 3.10 & 0.34 & 0.56 & 2.44 & 1.24 & 0.35 & 152 \\
Area 2 I (Univalem) & 467 & 4.02 & 0.38 & 2.45 & 2.44 & 1.54 & 0.74 & 116 \\
Area 2 II (Univalem) & 422 & 6.04 & 0.58 & 1.30 & 8.55 & 2.55 & 0.95 & 73 \\
\hline I and II denote the first and second sugarcane ratoon, respectively. Source: adapted from Lisboa et al. [19].
\end{tabular}

Overall, this study frames the development of models based on NDVI and plant nutritional status to predict sugarcane yield in field managed with straw removal. Plant tillering, growth, and stalk yield under the same straw management were discussed in detail by Lisboa et al. [19]. Thus, part of the primary data (i.e., amount of straw, characterization and stalk yield) presented on this study (mainly in Material and Methods) were originally shown in Lisboa et al. [19].

\subsection{Calculation of the NDVI}

The data were obtained in the field using the FieldSpec Spectroradiometer (ASD-Analytical Spectral Devices Inc., Boulder, CO, USA) hyperspectral sensor. This equipment is classified as a passive hyperspectral sensor that uses the visible and infrared wavelengths (325 to $1075 \mathrm{~nm}$ ), with a spectral resolution of $3 \mathrm{~nm}$ and a view angle of $25^{\circ}$. Before the canopy reading was initiated, the spectroradiometer was calibrated using the standard Lambertian plate that accompanies the apparatus. This calibration was repeated after reading approximately four plots or whenever a change of light intensity was observed in the field. The NDVI was calculated using Equation (1).

$$
N D V I=\frac{(\mathrm{NIR}-\mathrm{R})}{(\mathrm{NIR}+\mathrm{R})}
$$

where NDVI is the Normalized Difference Vegetation Index (unitless); NIR is the near infrared band and $\mathrm{R}$ is the red band; NIR represents the reflected light at the near infrared band and R represents the reflected light at the red band.

The field evaluations with the hyperspectral sensor were carried out on 28 April 2016 and 4 March 2016 for Areas 1 and 2, respectively, four months after harvesting. This period coincides 
with the recommended period for foliar diagnosis in sugarcane crop [31]. The evaluations were always carried out on sunny days, between 10:00 a.m. and 2:00 p.m., with the sensor positioned $1 \mathrm{~m}$ above the crop canopy and a field of view of $25^{\circ}$, which allowed the evaluation of a circular area of approximately $0.25 \mathrm{~m}^{2}$ (Figure 4).
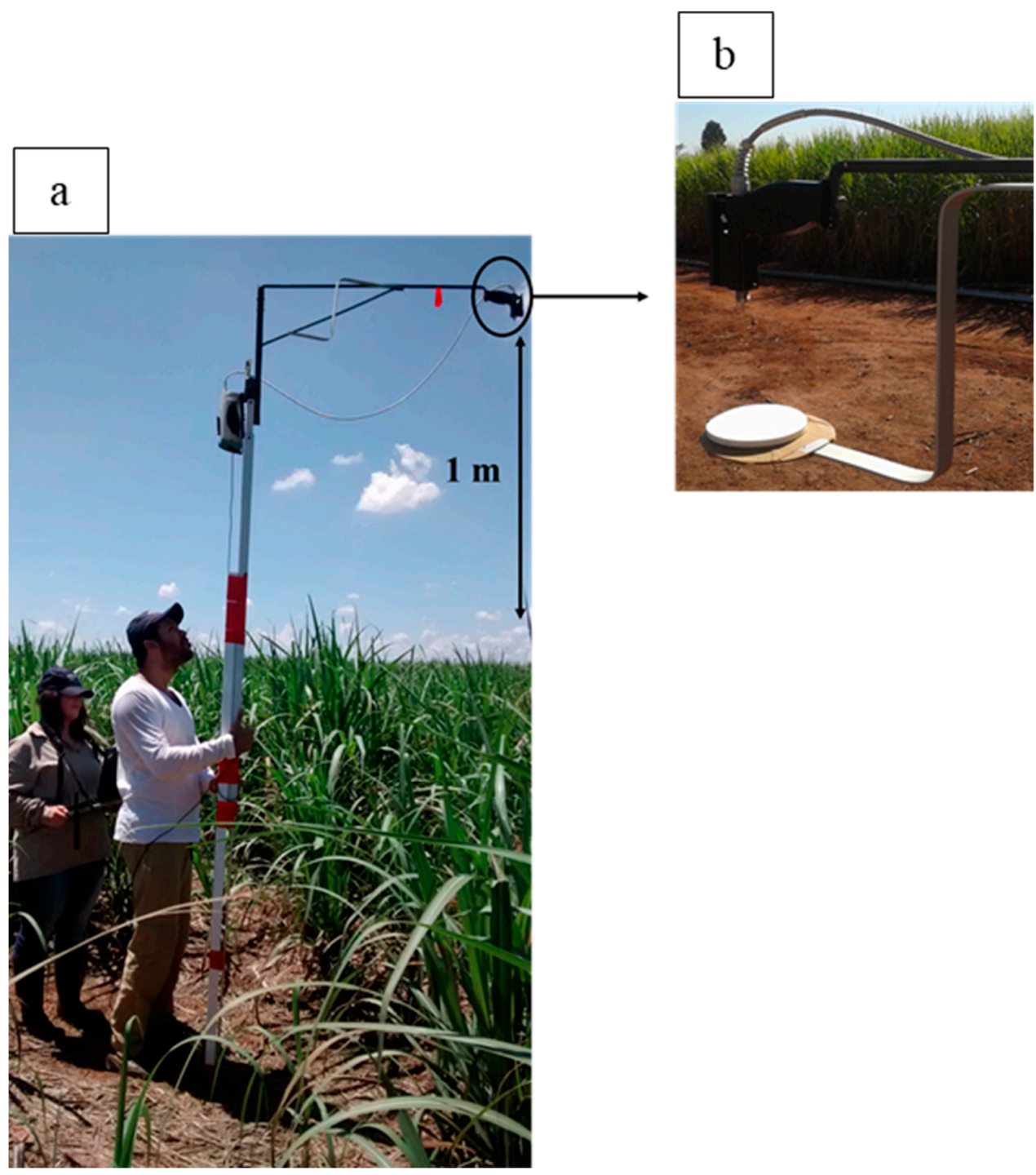

Figure 4. Representation of the hyperspectral sensor in the field (a) and Lambertini plate used for calibration (b).

The satellite images were obtained from the satellite CBERS-4 (China Brazil Earth Resources Satellite) on the 17 March 2016 and the 4 May 2016 for Areas 1 and 2, respectively. The images presented a spatial resolution of $5 \mathrm{~m}$, radiometric resolution of 8 bits and wavelength of $0.50-0.840 \mu \mathrm{m}$. As the panchromatic band of CBERS-4 was supplied in digital numbers without atmospheric calibration, the images were submitted to atmospheric correction according to Vermote et al. [32]. To perform NDVI calculations, the image was converted to surface reflectance according to the method described by Carlotto [33].

\subsection{Plant Parameters}

After measurements to calculate the NDVI, 50 leaves (i.e., the diagnose leaf) were randomly collected from each plot for the determination of the leaf-tissue nutrient content. The third leaf from 
top to bottom of the stalk with clearly visible dewlap, is the most photosynthetically active and is used for monitoring the nutritional status of sugarcane crop [31].

At the end of the ratoon cycle, approximately one year after previous harvesting, the sugarcane yield was quantified. The fresh stalk mass was mechanically harvested from the five central rows (500 $\mathrm{m}$ long covering an area of $525 \mathrm{~m}^{2}$ ) of each plot, weighed in the field using a wagon coupled to a balance and the results expressed in $\mathrm{Mg} \mathrm{ha}^{-1}$.

\subsection{Data Analysis}

The data were initially subjected to exploratory analysis (descriptive statistics), aiming to verify the position and dispersion of the data using the Statistical Analysis System (SAS) 9.4 Software Package for Windows 8 (SAS Inc, Cary, NC, USA).

In order to select the explaining variables of stalk yield, a stepwise multiple regression $\left(Y=a+b_{1} x^{1}+b_{2} x^{2}+\ldots+b_{n} x^{\mathrm{n}}\right)$ was applied. This functions by the systematic addition or removal of variables in the regression, based on a statistical test of significance for each variable $(p<0.05)$. The final model includes only those variables that have a decisive influence on the dependent variable. The models were evaluated according to the coefficient of determination, residual standard error and the Durbin-Watson test. The Durbin-Watson test ranges from 0 to 4 , where values closer to 2 indicate optimal values [34], i.e., the absence of autocorrelation in the data. The means of variables selected by stepwise multiple regression were compared according to Tukey's test $(p<0.05)$. In addition, the overall model that pools data from both studied areas was tested through sensitivity analysis, where position measurements (maximum, minimum, and mean) of each selected variable were inserted independently in the model, aiming to evaluate the resulting variations in sugarcane yield.

Finally, a model validation process was carried out with $30 \%$ of the data that were not used to generate the models. The relationship between the observed and predicted values were evaluated by the root mean square error (RMSE). The Pearson correlation matrix was also used to evaluate the relationship between observed and predicted productivity of sugarcane with variables selected with the stepwise models.

\section{Results}

\subsection{NDVI Values}

The NDVI obtained using the data from the hyperspectral sensor and the satellite images presented differences with respect to the distribution and magnitude of the values between the experimental areas (Figure 5). In Area 1, the NDVI values using the sensor and the satellite images ranged between 0.60 to 0.80 and 0.40 to 0.60 , respectively. However, in Area 2 the NDVI values were smaller, ranging between 0.40 to 0.70 and 0.20 to 0.50 for the sensor and the satellite images, respectively. On average, NDVI values (from both methodologies) were 34\% higher in Area 1 than in Area 2.

In both experimental areas, only the NDVI values derived from hyperspectral sensor followed a normal distribution (Figure 5). The largest differences were found in the NDVI values derived from the satellite images, especially when the removal rates were $25 \%$ and $50 \%$ for Area 1 and Area 2, which did not follow a normal data distribution. Although there are variations between NDVI derived by these two methods, the results showed a quite similar pattern in the variations of the NDVI data due to straw removal rates.

\subsection{Sugarcane Leaf-Tissue Nutrient Concentration}

The nutrient concentration in the sugarcane leaves varied according to the straw removal rate at both sites (Figures 6 and 7). The greatest variation was observed in the elements $\mathrm{K}$ ( 5 to $15 \mathrm{~g} / \mathrm{kg}^{-1}$ ) and $\mathrm{Ca}\left(2\right.$ to $\left.6 \mathrm{~g} / \mathrm{kg}^{-1}\right)$, whereas that the variation was less intense for the other elements. Despite that, for the majority of cases, nutrient data did not followed a normal distribution (Figures 6 and 7). 

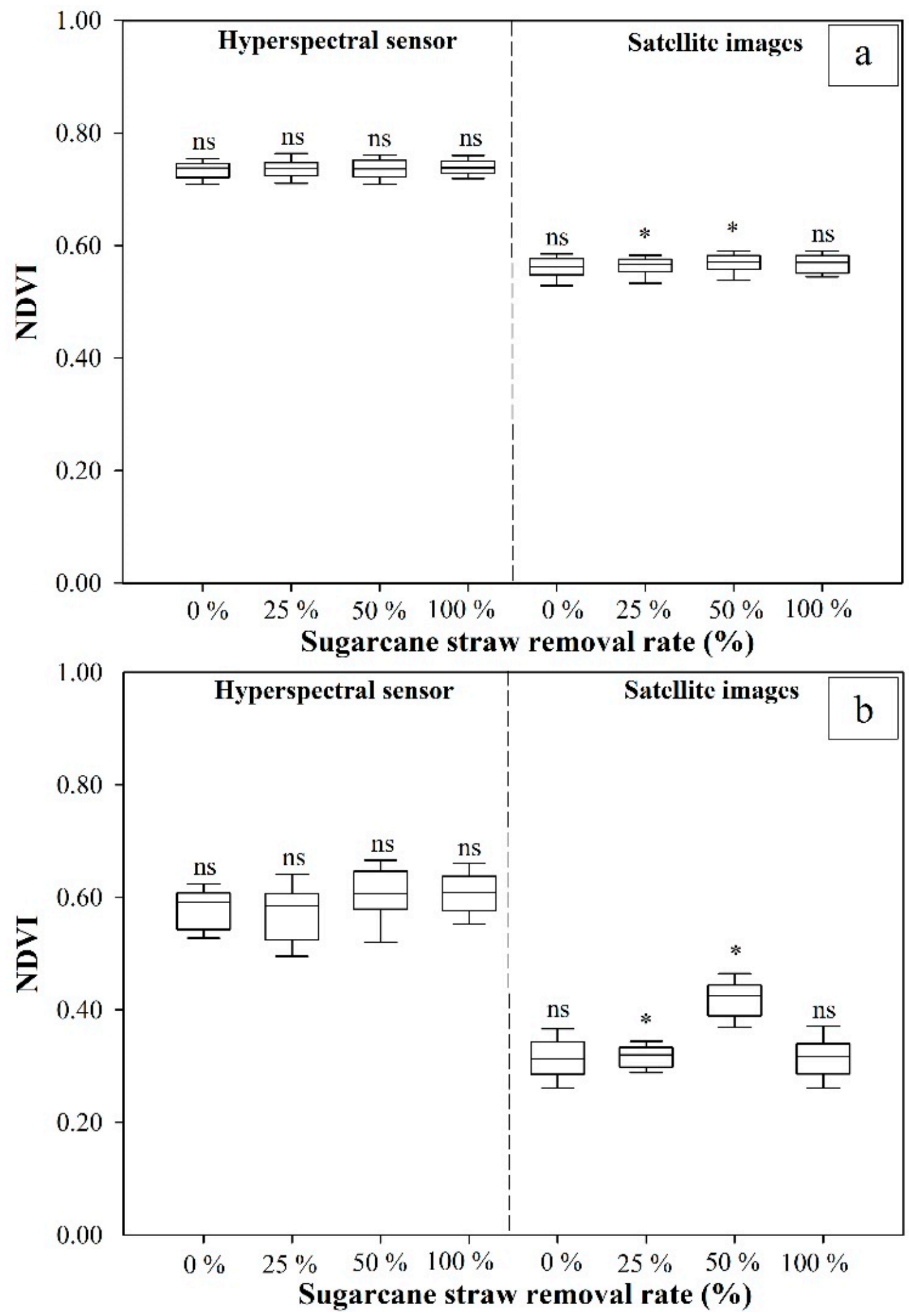

Figure 5. Values of NDVI for Areas 1 (a) and 2 (b) at the different rates of straw removal. Shapiro-Wilk Test for normal distribution, where: * significant $(p<0.05)$ and ns not significant. When significant, it indicates that the hypothesis for normal distribution is rejected. 


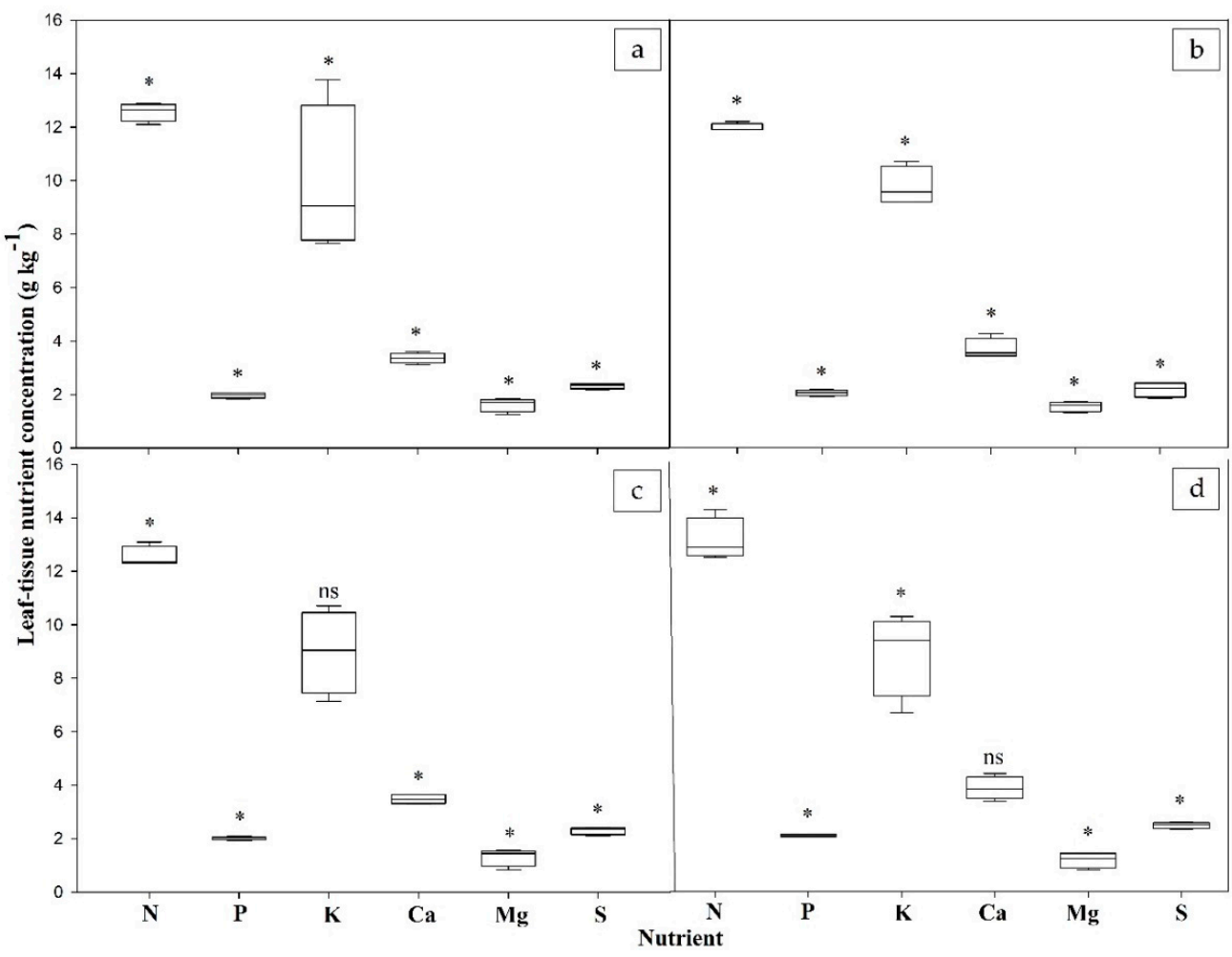

Figure 6. Leaf-tissue concentrations of $\mathrm{N}, \mathrm{P}, \mathrm{K}, \mathrm{Ca}, \mathrm{Mg}$, and $\mathrm{S}$ in sugarcane grown under straw removal rates of 0 (a), 25 (b), 50 (c), and 100\% (d) in Area 1. Shapiro-Wilk Test for normal distribution, where: * significant $(p<0.05)$ and ns not significant. When significant, it indicates that the hypothesis for normal distribution is rejected.

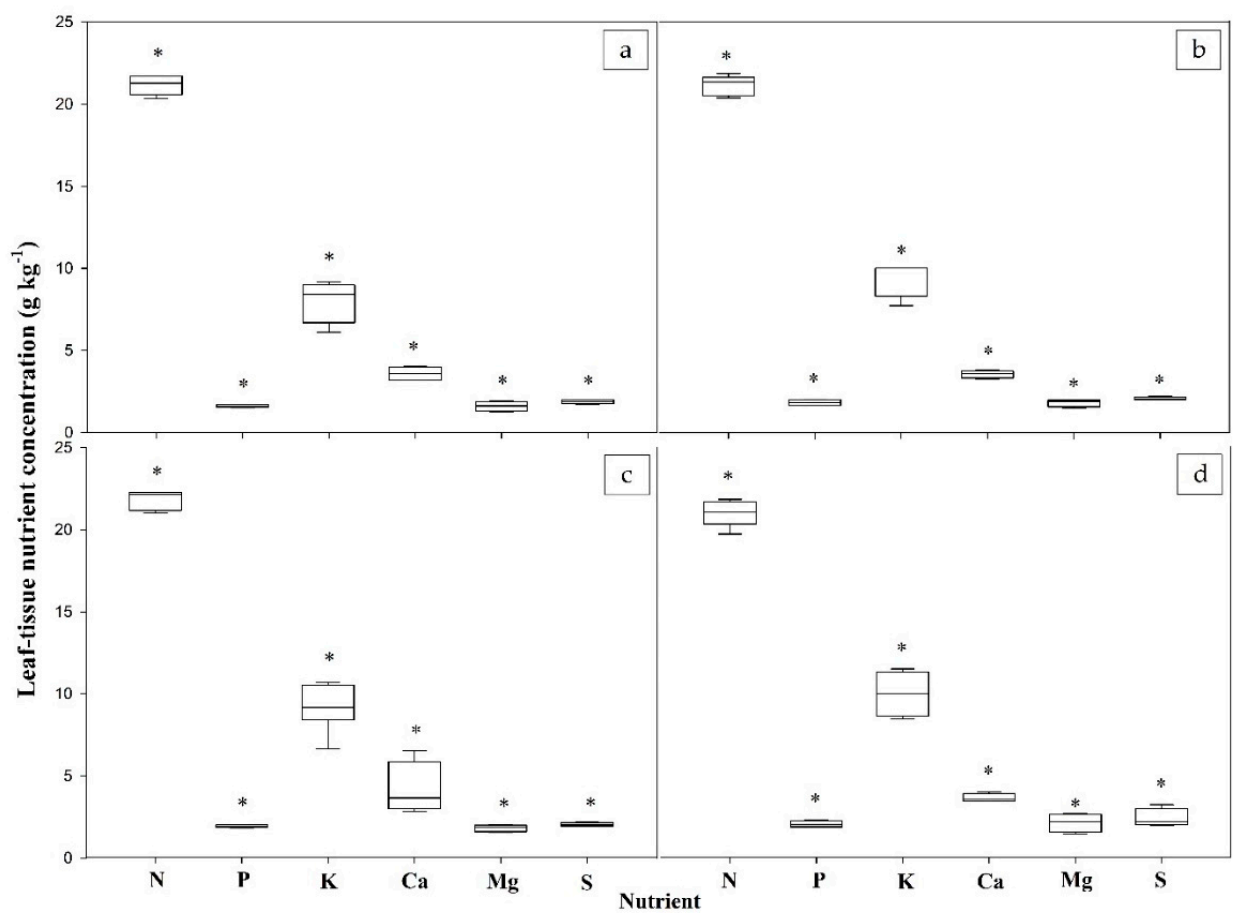

Figure 7. Leaf-tissue concentration of $\mathrm{N}, \mathrm{P}, \mathrm{K}, \mathrm{Ca}, \mathrm{Mg}$, and $\mathrm{S}$ in sugarcane grown under straw removal rates of $0(\mathbf{a}), 25(\mathbf{b}), 50(\mathbf{c})$, and 100\% (d) in Area 2. Shapiro-Wilk Test for normal distribution, where: * significant $(p<0.05)$ and ns not significant. When significant, it indicates that the hypothesis for normal distribution is rejected. 


\subsection{Sugarcane Yield}

Sugarcane yield varied from 60 to $85 \mathrm{Mg} \mathrm{ha}^{-1}$ and from 10 to $30 \mathrm{Mg} \mathrm{ha}^{-1}$ for the Areas 1 and 2, respectively. On average, sugarcane yield was three times higher in Area 1 than in Area 2 (Figure 8). Our findings showed that straw removal rates did not linearly affect sugarcane yield, but it depends on the site-specific characteristics related to soil, climate, and variety.
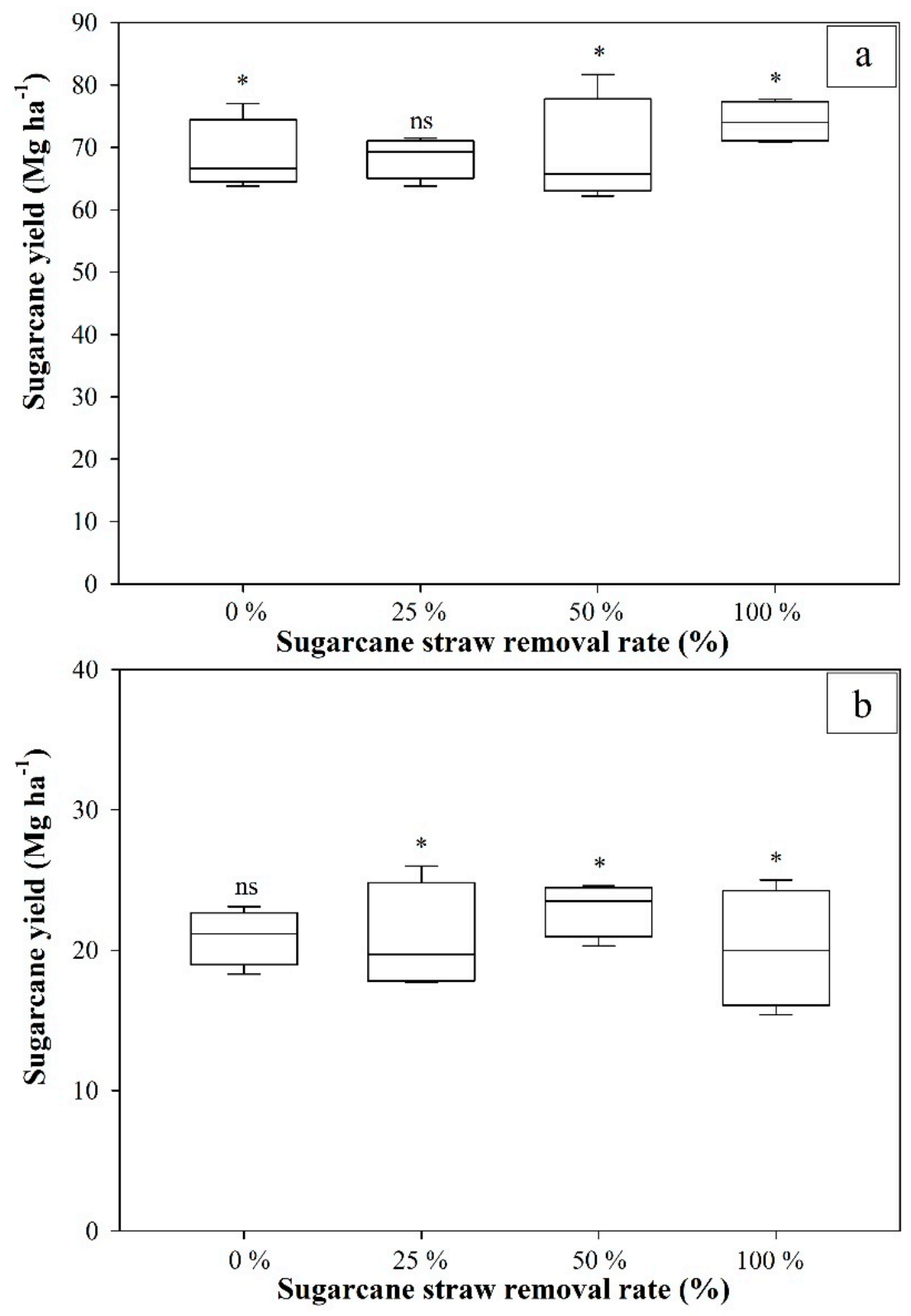

Figure 8. Sugarcane yield $\left(\mathrm{Mg} \mathrm{ha}^{-1}\right)$ changes induced by straw removal rates in Areas 1 (a) and 2 (b). Shapiro-Wilk Test for normal distribution, where: * significant $(p<0.05)$ and ns not significant. When significant, it indicates that the hypothesis for normal distribution is rejected.

The data did not follow a normal distribution for the majority of the treatments (Figure 8), except for data from $25 \%$ and $0 \%$ straw removal plots in Area 1 and 2, respectively.

\subsection{Modelling Sugarcane Yields by Stepwise Analysis}

Explaining variable of sugarcane yield were selected for each straw removal rate using stepwise analysis (Table 4). The NDVI obtained from satellite images was more efficient to predict sugarcane 
yield compared to NDVI derived from hyperspectral sensor, and therefore, this parameter was included in all the models.

Table 4. Stepwise models for estimating the components of sugarcane yield under straw removal rates in Areas 1 and 2.

\begin{tabular}{|c|c|c|c|c|}
\hline Straw Removal Rate (\%) & Models & $r^{2} *$ & SRE & DW \\
\hline \multicolumn{5}{|c|}{ Area 1} \\
\hline 0 & $y=205.38-48.66 \mathrm{P}-0.83 \mathrm{~K}-58.36 N D V I_{\mathrm{SI}}$ & 0.94 & 1.76 & 1.78 \\
\hline 25 & $y=546.65-58.07 \mathrm{P}-30.31 \mathrm{~N}+7.18 N D V I_{\mathrm{SI}}$ & 0.91 & 1.31 & 1.52 \\
\hline 50 & $y=322.62-108.24 \mathrm{P}-6.33 \mathrm{~N}+60.36 N D V I_{\mathrm{SI}}$ & 0.88 & 4.07 & 1.48 \\
\hline 100 & $y=193.25-56.54 \mathrm{P}+4.25 N D V I_{\mathrm{SI}}+0.27 \mathrm{~N}$ & 0.85 & 2.10 & 1.65 \\
\hline Overall (Area 1) & $\begin{array}{c}y=136.70+42.84 N D V I_{S I}-51.19 P+1.61 \mathrm{~N} \\
\text { Area } 2\end{array}$ & 0.97 & 2.56 & 1.56 \\
\hline 0 & $y=-13.20+1.75 \mathrm{~N}-13.76 \mathrm{NDVI}_{\mathrm{SI}}$ & 0.87 & 6.64 & 1.44 \\
\hline 25 & $y=-166.31+25.60 \mathrm{P}+6.51 \mathrm{~N}+22.76 N D V I_{\mathrm{SI}}$ & 0.91 & 8.65 & 1.65 \\
\hline 50 & $y=42.25-12.41 \mathrm{P}+22.23 N D V I_{\mathrm{SI}}$ & 0.76 & 4.50 & 1.59 \\
\hline 100 & $y=134.25-20.90 \mathrm{Ca}-20.51 \mathrm{P}+31.89 \mathrm{NDVI}_{\mathrm{SI}}$ & 0.94 & 4.29 & 1.56 \\
\hline Overall (Area 2) & $y=-127.21+3.80 N D V I_{S I}-0.26 \mathrm{~N}+54.88 \mathrm{P}$ & 0.88 & 3.86 & 1.61 \\
\hline Overall (Area 1 and Area 2) & $y=-150.028+79.11 N D V I_{S I}-3.65 \mathrm{~N}+115.28 \mathrm{P}$ & 0.89 & 1.79 & 1.72 \\
\hline
\end{tabular}

SRE: standard residual error (\%); DW: Durbin-Watson test. N: nitrogen; P: phosphorus; K: potassium; Ca: calcium; and $N D V I_{\mathrm{SI}}$ : NDVI obtained by satellite images. ${ }^{*}$ correlation coefficient.

The nutrients that most influenced crop yield were $\mathrm{P}$ and $\mathrm{N}$, being included in the model for at least one straw removal rate in both experimental areas; while the $\mathrm{K}$ and Ca were only included in the models for the removal rates of $0 \%$ and $25 \%$ for Area 1 and 100\% for Area 2. Overall models for Area 1 and 2, separately and together, included the parameters such as NDVI obtained from the satellite images, leaf-tissue concentration of $\mathrm{P}$ and $\mathrm{N}$.

The models presented efficient performance to predict the sugarcane yield (Table 4). In Area 1, the $r^{2}$ values varied between 0.85 and 0.94 with the highest SRE encountered under the $50 \%$ removal rate $(4.07 \%)$. The $r^{2}$ values varied between 0.76 and 0.94 for Area 2, with the highest SRE observed under the $25 \%$ removal rate $(8.65 \%)$. Although SRE of $8.65 \%$ was the highest value observed in the two areas it was considered acceptable by the validation of the model. In the overall models, the $r^{2}$ and SRE values for Areas 1 and 2 were $0.97 \%$ and $2.56 \%$, and $0.88 \%$ and $3.86 \%$, respectively, and for the general model representing both areas the $r^{2}$ and SRE values were $0.89 \%$ and $1.79 \%$, respectively. For the models generated individually for each straw removal rate in each of the two areas, for the general models for each area and for the general model representing both areas, the Durbin-Watson test values were similar, with values ranging between 1.44 and 1.78. These values were close to 2 (ideal threshold), showing that the data do not present autocorrelation [34]. The sensitivity analysis of the overall model for Areas 1 and 2, showed that yield ranged $11 \%$ (i.e., 39.2 to $52.5 \mathrm{Mg} \mathrm{ha}^{-1}$ ) when the selected parameter changed from the minimum to maximum value. Individually, variation on NDVI, $\mathrm{P}$, and $\mathrm{N}$ impacts were $55.84 \%, 55.03 \%$, and $53.10 \%$ in the sugarcane yield.

\subsection{Effect of Sugarcane Straw Removal on Selected Yield-Explaining Variables}

The comparison of the means of the selected variables by the stepwise model indicated that sugarcane yield was not altered by straw removal management within the study period (Figure 9a). In relation to the variables that explained the sugarcane yield, it was observed that $25 \%$ straw removal rate induced a reduction in the NDVI, using the satellite image data (Figure 9b), and the leaf-tissue $P$ content (Figure 9d) in Area 1. However, 50\% straw removal rate induced an increase in the NDVI, using the satellite image data (Figure 9b) and the leaf-tissue N (Figure 9c) and P (Figure 9d) contents in Area 2. 

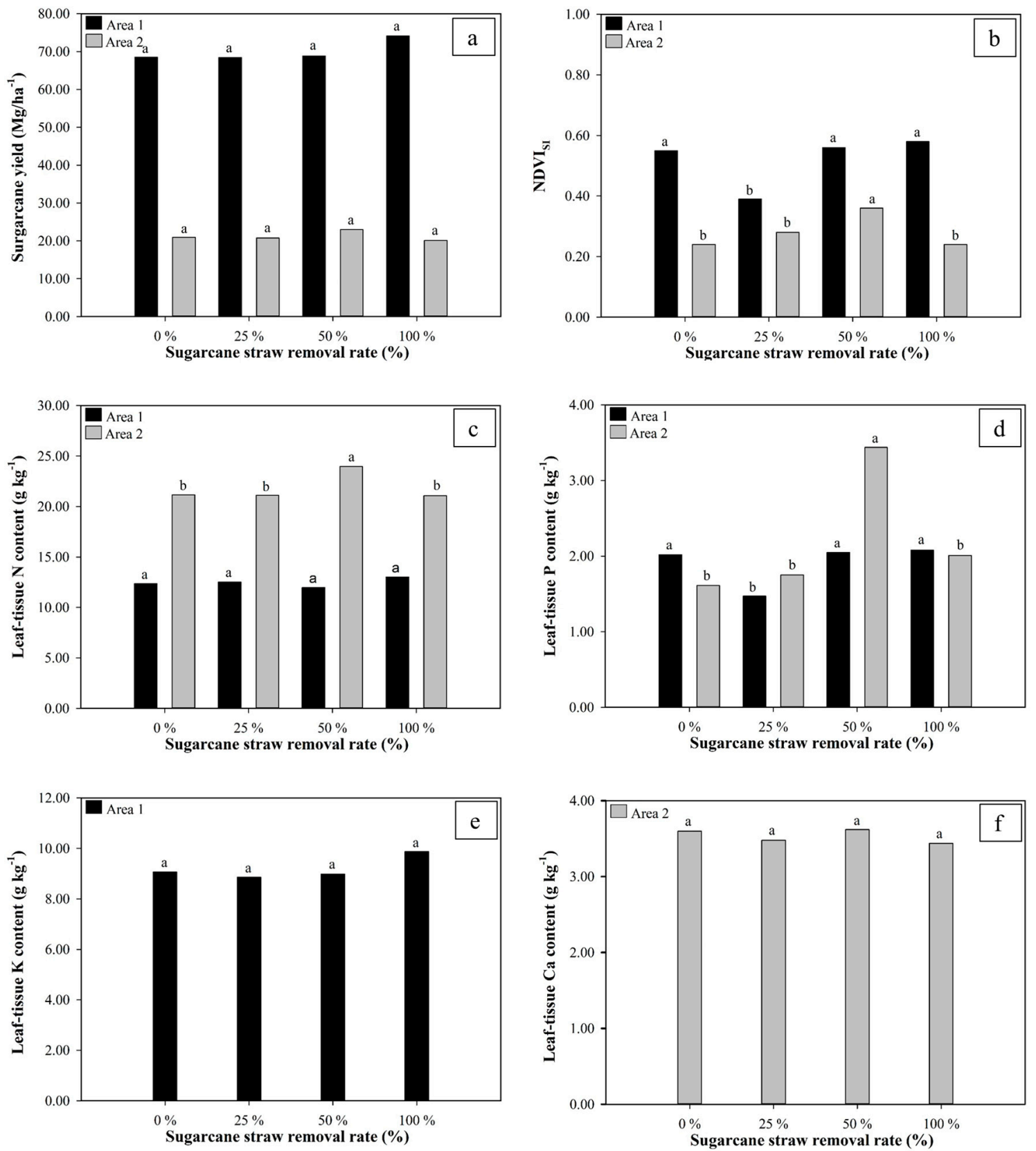

Figure 9. Comparison of the sugarcane straw removal rates with the variables selected by the stepwise model means. Sugarcane yield (a), the NDVI obtained from the satellite image data (b), leaf-tissue $\mathrm{N}(\mathbf{c}), \mathrm{P}(\mathbf{d}), \mathrm{K}(\mathbf{e})$, and Ca (f) contents in Areas 1 and 2. Means followed by the same letter are not statistically different by the Tukey test $(p \leq 0.05)$.

\subsection{Validation of Models}

The models were validated based on relationship between observed and predicted values (Figure 10). In general, the results revealed increases of estimate errors (i.e., RMSE values) with the increase in the straw removal rate ( $0 \%$ to $100 \%$ straw removal rate). The highest values were observed for the rates of $50\left(10.34 \mathrm{Mg} \mathrm{ha}^{-1}\right)$ and $100 \%\left(4.15 \mathrm{Mg} \mathrm{ha}^{-1}\right)$ for Areas 1 and 2 respectively. The overall model, including Areas 1 and 2, was efficient to predict the sugarcane yield, presenting RMSE of $0.77 \mathrm{Mg} \mathrm{ha}^{-1}$. 

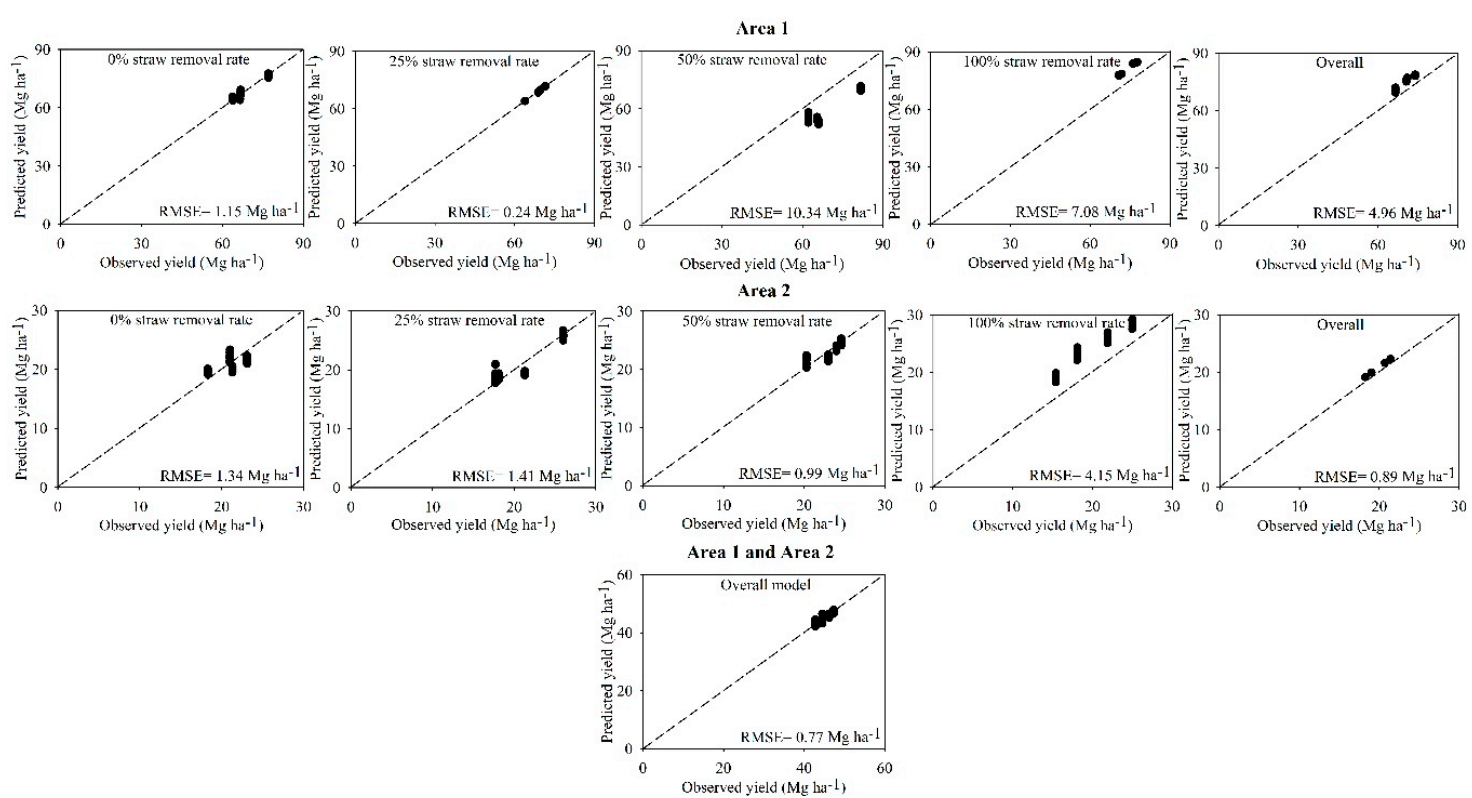

Figure 10. Comparison of sugarcane yield observed with predicted values with Stepwise models. The diagonal dashed line is the 1:1 line, whereas RMSE is the root mean square error.

Observed (OY) and predicted (PY) yield data presented satisfactory performance when compared to the variables selected through the stepwise models (Table 5). Leaf-tissue P concentration presented negative correlation with OY and PY yield data for the Area 1 subjected to all rates of straw removal (i.e., $0 \%, 25 \%, 50 \%$, and $100 \%$ ). Similar pattern was also observed to the general model for the same area. While for Area 2, P presented negative correlation with PY and OY data only under $50 \%$ of straw removal. In addition, $\mathrm{N}$ presented positive and significant correlations with $\mathrm{OY}$ and PY data from Area 1 under $50 \%$ and $100 \%$ of straw removal as well as for general model for this area, coefficients of correlation $(r)$ ranged from 0.33 to 0.68 . The correlations among NDVI $I_{\mathrm{SI}}, \mathrm{OY}$, and PY data were positive for all rates of straw removal and overall model for the area 1. Same pattern was verified for all rates of straw removal in the Area 2, except for the rate of $25 \%$ of straw removal; coefficients of correlation ranged from -0.40 to 0.93 in Area 2 .

It taking into account overall model established for both areas, leaf-tissue concentrations of $\mathrm{P}$ and $\mathrm{N}$ were significantly correlated with stalk yield, but in different order, as follow: $\mathrm{P}$ negatively correlated with OY $(r=-0.45)$ and PY $(r=-0.50)$ data, while $\mathrm{N}$ was positively correlated with OY $(r=0.55)$ and PY $(r=0.58)$ data. Similarly, NDVI $\mathrm{SI}$ correlated positively with $\mathrm{OY}(r=0.60, p<0.05)$ and PY $(r=0.68, p<0.05)$ data. 
Table 5. Correlation matrix between observed and predicted sugarcane yield values with selected variables with stepwise models.

\begin{tabular}{|c|c|c|c|c|c|c|c|c|c|c|c|c|}
\hline \multicolumn{7}{|c|}{ Area 1} & \multicolumn{6}{|c|}{ Area 2} \\
\hline \multicolumn{13}{|c|}{$0 \%$} \\
\hline & $\mathrm{P}$ & $\mathrm{K}$ & $N D V I_{\mathrm{SI}}$ & OY & PY & & & $\mathrm{N}$ & $N D V I_{\mathrm{SI}}$ & OY & PY & \\
\hline $\mathrm{P}$ & - & & & & & & $\mathrm{N}$ & - & & & & \\
\hline K & 0.19 & - & & & & & $N D V I_{\mathrm{SI}}$ & -0.14 & - & & & \\
\hline$N D V I_{\mathrm{SI}}$ & -0.23 & 0.22 & - & & & & OY & 0.54 * & 0.37 * & - & & \\
\hline OY & $-0.84^{* *}$ & 0.60 ** & $0.71^{* *}$ & - & & & PY & $0.87^{* *}$ & $0.60 * *$ & $0.75^{* *}$ & - & \\
\hline PY & $-0.86^{* *}$ & $0.62 * *$ & $0.74^{* *}$ & $0.97^{* *}$ & - & & & & & & & \\
\hline \multicolumn{13}{|c|}{$25 \%$} \\
\hline & $\mathrm{P}$ & $\mathrm{N}$ & $N D V I_{\mathrm{SI}}$ & OY & PY & & & $\mathrm{P}$ & $\mathrm{N}$ & $N D V I_{\mathrm{SI}}$ & OY & PY \\
\hline $\mathrm{P}$ & - & & & & & & $\mathrm{P}$ & - & & & & \\
\hline $\mathrm{N}$ & $-0.85^{* *}$ & - & & & & & $\mathrm{N}$ & $-0.49 *$ & - & & & \\
\hline$N D V I_{\mathrm{SI}}$ & 0.01 & 0.38 & - & & & & $N D V I_{\mathrm{SI}}$ & $-0.56^{*}$ & 0.02 & - & & \\
\hline $\mathrm{OY}^{\mathrm{I}}$ & $-0.62 *$ & 0.25 & 0.50 * & - & & & OY & $0.62 * *$ & 0.23 & $-0.37^{*}$ & - & \\
\hline PY & $-0.71^{* *}$ & 0.23 & $0.45^{*}$ & $0.98^{* *}$ & - & & PY & $0.68^{* *}$ & 0.26 & -0.40 * & 0.90 ** & - \\
\hline \multicolumn{13}{|c|}{$50 \%$} \\
\hline & $\mathrm{P}$ & $\mathrm{N}$ & $N D V I_{\mathrm{SI}}$ & OY & PY & & & $\mathrm{P}$ & $N D V I_{\mathrm{SI}}$ & OY & PY & \\
\hline $\mathrm{P}$ & - & & & & & & $\mathrm{P}$ & - & & & & \\
\hline $\mathrm{N}$ & 0.15 & - & & & & & $N D V I_{\mathrm{SI}}$ & $-0.41 *$ & - & & & \\
\hline$N D V I_{\mathrm{SI}}$ & -0.16 & $0.46^{*}$ & - & & & & OY & $-0.73^{* *}$ & $0.60^{* *}$ & - & & \\
\hline OY & $-0.90^{* *}$ & 0.33 * & $0.84^{* *}$ & - & & & PY & $-0.88^{* *}$ & $0.76^{* *}$ & $0.89 * *$ & - & \\
\hline PY & $-0.96^{* *}$ & 0.35 * & $0.81 * *$ & $0.93 * *$ & - & & & & & & & \\
\hline \multicolumn{13}{|c|}{$100 \%$} \\
\hline & $\mathrm{P}$ & $\mathrm{N}$ & $N D V I_{\mathrm{SI}}$ & OY & PY & & & $\mathrm{P}$ & $\mathrm{Ca}$ & $N D V I_{\mathrm{SI}}$ & OY & PY \\
\hline $\mathrm{P}$ & - & & & & & & $\mathrm{P}$ & - & & & & \\
\hline $\mathrm{N}$ & $-0.62 * *$ & - & & & & & $\mathrm{Ca}$ & $-0.54 *$ & - & & & \\
\hline$N D V I_{\mathrm{SI}}$ & $-0.39 *$ & 0.25 & - & & & & $N D V I_{\mathrm{SI}}$ & 0.23 & 0.30 & - & & \\
\hline OY & $-0.96^{* *}$ & $0.56^{* *}$ & $0.73^{* *}$ & - & & & OY & -0.22 & $0.64^{* *}$ & 0.30 & - & \\
\hline PY & $-0.91^{* *}$ & $0.64^{* *}$ & $0.61^{* *}$ & $0.98^{* *}$ & - & & PY & -0.14 & $0.72 * *$ & 0.29 & $0.97^{* *}$ & - \\
\hline \multicolumn{13}{|c|}{ Overall } \\
\hline & $\mathrm{P}$ & $\mathrm{N}$ & $N D V I_{\mathrm{SI}}$ & OY & PY & & & $\mathrm{P}$ & $\mathrm{N}$ & $N D V I_{\mathrm{SI}}$ & OY & PY \\
\hline $\mathrm{P}$ & - & & & & & & $\mathrm{P}$ & - & & & & \\
\hline $\mathrm{N}$ & $0.95^{* *}$ & - & & & & & $\mathrm{N}$ & $0.84^{* *}$ & - & & & \\
\hline$N D V I_{\mathrm{SI}}$ & $-0.54 *$ & -0.28 & - & & & & $N D V I_{\mathrm{SI}}$ & -0.24 & 0.12 & - & & \\
\hline OY & $-0.84^{* *}$ & $0.68^{* *}$ & $0.86^{* *}$ & - & & & OY & -0.28 & -0.26 & $0.61^{* *}$ & - & \\
\hline PY & $-0.81 * *$ & $0.61^{* *}$ & $0.93 * *$ & $0.96^{* *}$ & - & & PY & -0.24 & -0.28 & $0.69 * *$ & $0.97^{* *}$ & - \\
\hline
\end{tabular}


Table 5. Cont.

\begin{tabular}{|c|c|c|c|c|c|c|}
\hline Area 1 & & & & & & Area 2 \\
\hline \multicolumn{7}{|c|}{ Overall (Area 1 and Area 2) } \\
\hline & & $\mathrm{P}$ & $\mathrm{N}$ & $N D V I_{S I}$ & OY & PY \\
\hline & $\mathrm{P}$ & - & & & & \\
\hline & $\mathrm{N}$ & $0.96^{* *}$ & - & & & \\
\hline & $N D V I_{\mathrm{SI}}$ & -0.08 & 0.08 & - & & \\
\hline & OY & $\begin{array}{c}-0.45 \\
*\end{array}$ & $0.55^{*}$ & $0.60 * *$ & - & \\
\hline & PY & $\begin{array}{c}-0.50 \\
*\end{array}$ & $0.58 *$ & $0.68^{* *}$ & $0.90 * *$ & - \\
\hline
\end{tabular}

*** Significant at $p<0.05$ and $p<0.01$, respectively. OY: observed yield; PY: predicted yield; N: nitrogen; P: phosphorous; K: potassium; Ca: calcium and NDVI satellite images. 


\section{Discussion}

\subsection{Effect of Straw Removal on the Leaf-Tissue Nutrient Concentration and Sugarcane Yield}

Sugarcane straw removal had little or even no impacts on leaf-tissue nutrient content (Figures 6 and 7). Nutrient cycling in the soil was minimally affected by the straw removal rates in the short term [12], and therefore, plant nutrition was little affected. Among the evaluated elements, $\mathrm{K}$ and $\mathrm{Ca}$ presented the largest variations in both experimental areas. The sugarcane straw can recycle about 80-100 $\mathrm{kg} \mathrm{ha}^{-1}$ of $\mathrm{K}[35,36]$. According to Rosolem et al. [37], more than $80 \%$ of the $\mathrm{K}$ is present in a soluble form in plant tissues, which makes this element easily leached from plant tissues [9] for later absorption by the plant root system. Unbalanced absorption of $\mathrm{K}$ may also change Ca content in plant tissues, since both elements interfere in the physiological process of transporting sugars into the plant [38].

Although $\mathrm{K}$ and Ca were the most variable in the plant tissues as a function of straw removal, $\mathrm{N}$ and $\mathrm{P}$ were the most sensitive nutrients to the straw removal rates (Figure $9 \mathrm{c}, \mathrm{d}$ ). When compared to other nutrients-such as $\mathrm{P}, \mathrm{K}, \mathrm{Ca}, \mathrm{Mg}$, and $\mathrm{S}-\mathrm{N}$ presented the largest reduction in the soil with straw removal [39]. On the other hand, straw removal led to small reductions in the level of soil $\mathrm{P}$, since the content of this element in straw is low (Table 3). However, the majority of $\mathrm{P}$ is highly adsorbed in the soil particles (especially Fe and Al oxides) [40], thus, small inputs of P in organic forms via straw decomposition can be important to increase plant-availability $\mathrm{P}$ in the soils [41]. In addition, the organic acids released during straw decomposition may compete for adsorption sites and increase the availability of phosphate ions in the soil solution [42].

The sugarcane yield varied three times between the two areas evaluated (Figure 8). This difference may be related to the greater soil fertility of Area 1, in which soil $\mathrm{P}, \mathrm{K}, \mathrm{Ca}$, and $\mathrm{Mg}$ contents and base saturation percentage were on the average $42 \%, 55 \%, 69 \%, 67 \%$, and $29 \%$, respectively higher than Area 2. Thus, higher soil fertility in Area 1 likely allowed that plants accumulate higher levels of these nutrients in the leaf tissue, which is directly related to the increase of the sugarcane yield [43]. Sugarcane presents high nutritional needs once it a crop that remains in the field for several years ( $\sim 5$ to 8 years), with high nutrient removal in each annual harvesting cycle. Therefore, improper replenishment of nutrients is one of the reasons for yield loss during the annual harvesting cycles [44,45].

The sugarcane straw removal did not affect biomass production (Figure 9a). These results are in agreement with other studies reporting that the removal of up to 50\% of the straw produced did not impact crop yield $[18,19,46]$. In addition, through an extensive literature review, Carvalho et al. [9] suggested that at least $7 \mathrm{Mg} \mathrm{ha}^{-1}$ of straw should remain on the soil surface to sustain suitable soil functioning and plant yield over time. However, as the crop tends to lose the productive potential (stalk and straw) over successive harvesting cycles $[19,47]$, the amount of straw that should be removed after each harvesting cycle may be different.

Over the past few years, studies have brought very relevant understanding about the impacts of straw removal management on soil quality [12,14,36,48], SOC accumulation [49,50], greenhouse gas emissions [51-53], plant growth and stalk yield [18,19,46,54-56]. Despite this fact, future studies are essential to understand the long-term implications of straw removal management on soil and stalk yield. So far, we only have prediction performed by DayCent model of sugarcane straw removal impacts on SOC accumulation across the different soil types within the main core occupied with the crop in Brazil (i.e., central-south region) [49,50]. However, these estimates performed by Carvalho et al. [49] and Oliveira et al. [50] still have to be validated by long-term experiment, still inexistent in Brazil. The same statement is true for the yield prediction models developed in this present study, which gave us relevant insights related to the potentialities of NVDI and leaf-tissue nutrient concentration to predict sugarcane yield in fields impacted by straw removal management. 


\subsection{NDVI Acquisition by Satellite Image vs Hyperspectral Sensor}

The quality of the data used to calculate the NDVI is affected by interference from diverse factors, depending on the form of data acquisition. When satellite images are used, although the data is collected with minimum cloud cover, the interference of these few clouds at the moment of data acquisition could alter the quality of the incident and reflected radiation [57]. Besides this, the capture of satellite images tends to suffer a greater influence from the soil than that experienced using the hyperspectral sensor, where readings are taken above the canopy and rows with minimal soil influence. Thus, the NDVI values using satellite images are normally lower [58]. These interferences explain the difference of $34 \%$ observed between the NDVI using the hyperspectral sensor those obtained using satellite images for the sugarcane in the two experimental areas (Figure 5). Although several studies have shown a high correlation between the NDVI obtained using hyperspectral sensor and satellite image data $[59,60]$, we suggest caution when choosing the spectral data acquisition platform to calculate the NDVI.

The NDVI from the satellite images data was included in all the models generated (Table 4) and was efficient for detecting the effects of straw removal rates on sugarcane yield in Areas 1 and 2 (Figure 9b). In spite of limitations attributed to NDVI data derived from satellite images, the results showed that acquired data from satellite images better represented the variation in sugarcane yield [61]. This type of data acquisition has the advantage that it can be applied for larger areas in relation to the data acquired using hyperespectral sensors, which are generally limited to smaller areas of the crop canopy.

\subsection{Sugarcane Yield Prediction Using the NVDI and Leaf-Tissue Nutrient Concentration}

In all the stepwise models established to estimate sugarcane yield as a function of each straw removal rate, the NDVI was included (Table 4). This inclusion can be explained by the fact that most of models used to estimate sugarcane yield are based on the estimated biomass production [62]. This would explain, at least in part, the efficiency of the NDVI to detect stalk yield changes as a function of the straw removal rates, as this index has a high correlation with crop biomass [63].

Among the nutrients included in the site-specific models (i.e., N, P, and $\mathrm{K}$ for Area 1; and N, $\mathrm{P}$, and Ca for Area 2), only N and P were included in the overall model for the two areas (Table 4). Nutrients such as $\mathrm{N}$ and $\mathrm{P}$ are present in larger quantities in younger plants, being more sensitive to changes caused by different management systems [64,65]. In addition, the relationship of these nutrients with the NDVI in the models was expected due to the influence of these elements on the photosynthetic process, which in turn, change the spectral responses by the plant, influencing the NDVI $[66,67]$. In this approach, other studies can be performed to identify the spectral signatures of the nutrients in the leaves so that the model can only be applied using spectral data.

The performance of the models in the validation process were also satisfactory when observed RMSE values between the rates of $0 \%$ to $100 \%$, ranged from 0.24 to $10.34 \mathrm{Mg} \mathrm{ha}^{-1}$ for the area 1 and 0.99 to $4.15 \mathrm{Mg} \mathrm{ha}^{-1}$ for Area 2 (Figure 10). These values agree with those reported by Fernandes et al. [68], which found RMSE values of predicted sugarcane yields ranged from 7.20 to $11.00 \mathrm{Mg} \mathrm{ha}^{-1}$. In addition, the sensitivity analysis showed that overall model for Areas 1 and 2 provides a satisfactory margin for the prediction of sugarcane yield with similar soil and climate conditions of this study. Therefore, the overall model performance showed NDVI from satellite images and leaf-tissue nutrient concentrations can be useful and alternative tool to improve the sugarcane yield predictions.

\section{Conclusions}

The normalized difference vegetation index (NDVI) can be a useful tool for predicting sugarcane yield in fields managed with straw removal management in Brazil. Between the methods of data acquisition to calculate NDVI, satellite image was more efficient than hyperspectral sensor for detecting 
straw removal effects on sugarcane yield. In addition, concentrations of leaf-tissue $\mathrm{N}$ and $\mathrm{P}$ were also important parameters to develop the prediction models of sugarcane yield.

Prediction model approach based on data of NDVI and concentration of leaf-tissue nutrients collected in early stages of crop growth can help the Brazilian sugarcane sector to predict crop yield in fields intensively managed for bioenergy production. In addition, these models can be used for monitoring spatio-temporal crop yield changes induced by straw removal and supporting decision making towards a more sustainable crop residue management in Brazilian sugarcane fields. The sugarcane yield prediction models developed in this study have to be further tested and validated using data from long-term straw removal experiments, so far, still inexistent in Brazil.

Author Contributions: I.P.L.: field sampling, writing, review; J.M.D.: data analyses, writing, review; M.R.C.: writing and review; P.P.S.B.: field sampling and writing; P.R.F.: financial support and writing; C.C.C.: this paper is in his memory; C.E.P.C.: financial support, writing and review.

Funding: I.P.L. thanks The Brazilian Federal Agency for Support and Evaluation of Graduate Education (CAPES process \#88881.134605/2016-01) and CNPq (processes \#141459/2015-8 and \#201207/2017-6) for providing his Ph.D. scholarships in Brazil and the United States. M.R.C. thanks the "Fundação de Estudos Agrários Luiz de Queiroz" (project \#67555) for providing his post-doctoral fellowship. Also, we want to thank the Brazilian Development Bank-BNDES and the Raízen Energia S/A for funding our research (project \#14.2.0773.1).

Acknowledgments: We are grateful to Lilian Duarte, Admilson Margato, Ralf Araújo, Sandra Nicolete, Dagmar Vasca and Eleusa Basse for the strong assistance in the experiment conduction and samples analyses in the laboratory.

Conflicts of Interest: The authors declare no conflict of interest.

\section{References}

1. FAO—Food and Agriculture Organization. Available online: http://faostat.fao.org/ (accessed on 25 July 2018).

2. Companhia Nacional de Abastecimento-Conab. Available online: https://www.conab.gov.br/ (accessed on 25 July 2018).

3. REN21-Highlights of the REN21 Renewables 2017 Global Status Report in Perspective. Available online: http://www.ren21.net/wp-content/uploads/2017/06/GSR2017_Highlights_FINAL.pdf (accessed on 15 June 2018).

4. Goldemberg, J.; Mello, F.F.; Cerri, C.E.; Davies, C.A.; Cerri, C.C. Meeting the global demand for biofuels in 2021 through sustainable land use change policy. Energy Policy 2014, 69, 14-18. [CrossRef]

5. de Expansão de Energia 2024. Available online: http:/ / www.epe.gov.br (accessed on 1 May 2018).

6. Cunha, F.M.; Badino, A.C.; Farinas, C.S. Effect of a novel method for in-house cellulase production on 2G ethanol yields. Biocatal. Agric. Biotechnol. 2017, 9, 224-229. [CrossRef]

7. Lisboa, I.P.; Cherubin, M.R.; Cerri, C.C.; Cerri, D.G.P.; Cerri, C.E.P. Guidelines for the recovery of sugarcane straw from the field during harvesting. Biomass Bioenergy 2017, 96, 69-74. [CrossRef]

8. Leal, M.R.L.V.; Galdos, M.V.; Scarpare, F.V.; Seabra, J.E.A.; Walter, A.; Oliveira, C.O.F. Sugarcane straw availability, quality, recovery and energy use: A literature review. Biomass Bioenergy 2013, 53, 11-19. [CrossRef]

9. Carvalho, J.L.N.; Nogueirol, R.C.; Menandro, L.M.S.; Bordonal, R.D.O.; Borges, C.D.; Cantarella, H.; Franco, H.C.J. Agronomic and environmental implications of sugarcane straw removal: A major review. Glob. Chang. Biol. Bioenergy 2017, 9, 1181-1195. [CrossRef]

10. Cherubin, M.R.; Oliveira, D.M.S.; Feigl, B.J.; Pimentel, L.G.; Lisboa, I.P.; Gmach, M.R.; Varanda, L.L.; Moraes, M.C.; Satiro, L.S.; Popin, G.V.; et al. Crop residue harvest for bioenergy production and its implications on soil functioning and plant growth: A review. Sci. Agric. 2018, 75, 255-272. [CrossRef]

11. Corrêa, S.T.R.; Carvalho, J.L.N.; Hernandes, T.A.D.; Barbosa, L.C.; Menandro, L.M.S.; Leal, M.R.L.V. Assessing the effects of different amountsof sugarcane straw on temporal variability of soil moisture content and temperature. In Proceedings of the 25th European Biomass Conference and Exhibition, Stockholm, Sweden, 12-15 June 2017; pp. 12-15.

12. Satiro, L.S.; Cherubin, M.R.; Safanelli, J.L.; Lisboa, I.P.; Junior, P.R.R.; Cerri, C.E.E.; Cerri, C.C. Sugarcane straw removal effects on Ultisols and Oxisols in south-central Brazil. Geod. Reg. 2017, 11, 86-95. [CrossRef] 
13. Dos Anjos, J.C.R.; Júnior, A.S.A.; Bastos, E.A.; Noleto, D.H.; Melo, F.B.; De Brito, R.R. Water storage in a Plinthaqualf cultivated with sugarcane under straw levels. Pesqui. Agropecu. Brasil. 2017, 52, 464-473. [CrossRef]

14. Bordonal, R.O.; Menandro, L.M.S.; Barbosa, L.C.; Lal, R.; Milori, D.M.B.P.; Kolln, O.T.; Franco, H.C.J.; Carvalho, J.L.N. Sugarcane yield and soil carbon response to straw removal in south-central Brazil. Geoderma 2018, 328, 79-90. [CrossRef]

15. Fortes, C.; Vitti, A.C.; Otto, R.; Ferreira, D.A.; Franco, H.C.J.; Trivelin, P.C.O. Contribution of nitrogen from sugarcane harvest residues and urea for crop nutrition. Sci. Agric. 2013, 70, 313-320. [CrossRef]

16. Paredes Junior, F.P.; Portilho, I.I.R.; Mercante, F.M. Atributos microbiológicos de um latossolo sob cultivo de cana-de-açúcar com e sem queima da palhada. Semin. Ciênc. Agrár. 2015, 36, 151-164. [CrossRef]

17. Valim, W.C.; Panachuki, E.; Pavei, D.S.; Sobrinho, T.A.; Almeida, W.S. Effect of sugarcane waste in the control of interrill erosion. Semin. Ciênc. Agrár. 2016, 37, 1155-1164. [CrossRef]

18. Aquino, G.S.; Medina, C.C.; Costa, D.C.; Shahaba, M.; Santiago, A.D.; Cunha, A.C.B.; Kussaba, D.A.O.; Carvalho, J.B.; Moreira, A. Does straw mulch partial-removal from soil interfere in yield and industrial quality sugarcane? A long term study. Ind. Crops Prod. 2018, 111, 573-578. [CrossRef]

19. Lisboa, I.P.; Cherubin, M.R.; Lima, R.P.; Cerri, C.C.; Satiro, L.S.; Wienhol, B.J.; Schmer, M.R.; Jin, V.L.; Cerri, C.E.P. Sugarcane straw removal effects on plant growth and stalk yield. Ind. Crops Prod. 2018, 111, 794-806. [CrossRef]

20. Tucker, C.J.; Holben, B.N.; Elgin, J.H.; Mcmurtrey, J.E. Relationship of spectral data to grain yield variation. Photogramm. Eng. Remote Sens. 1980, 46, 657-666.

21. Tarnavsky, E.; Garrigues, S.; Brown, M.E. Multiscale geostatistical analysis of AVHRR, SPOT-VGT, and MODIS global NDVI products. Remote Sens. Environ. 2008, 112, 535-549. [CrossRef]

22. Sanches, G.M.; Duft, D.G.; Kölln, O.T.; Luciano, A.C.; De Castro, S.G.; Okuno, F.M.; Franco, H.C. The potential for RGB images obtained using unmanned aerial vehicle to assess and predict yield in sugarcane fields. Int. J. Remote Sens. 2018, 15, 1-3. [CrossRef]

23. Peralta, N.R.; Assefa, Y.; Du, J.; Barden, C.J.; Ciampitti, I.A. Mid-season high-resolution satellite imagery for forecasting site-specific corn yield. Remote Sens. 2016, 8, 1-16. [CrossRef]

24. Damian, J.M.; Santi, A.L.; Fornari, M.; Da Ros, C.O.; Eschner, V.L. Monitoring variability in cash-crop yield caused by previous cultivation of a cover crop under a no-tillage system. Comput. Electron. Agric. 2017, 142, 607-621. [CrossRef]

25. Lofton, J.; Tubana, B.S.; Kanke, Y.; Teboh, J.; Viator, H.; Dalen, M. Estimating sugarcane yield potential using an in-season determination of normalized difference vegetative index. Sensors 2012, 12, 7529-7547. [CrossRef] [PubMed]

26. Yang, H.; Yang, X.; Heskel, M.; Sun, S.; Tang, J. Seasonal variations of leaf and canopy properties tracked by ground-based NDVI imagery in a temperate forest. Sci. Rep. 2017, 1267, 1-10. [CrossRef] [PubMed]

27. Sardans, J.; Grau, O.; Chen, H.Y.H.; Janssens, I.A.; Ciais, P.; Piao, S.; Peñuelas, J. Changes in nutrient concentrations of leaves and roots in response to global change factors. Glob. Chang. Biol. 2017, 23, 3849-3856. [CrossRef]

28. USDA-United States Department of Agriculture. Available online: https://www.usda.gov / (accessed on 18 June 2018).

29. CEPAGRI-Tempo e Clima Unicamp. Available online: https://www.cpa.unicamp.br (accessed on 2 February 2017).

30. Posto Meteorológico "Professor Jesus Marden dos Santos” ESALQ—USP. Available online: http://www.leb. esalq.usp.br/posto/ (accessed on 2 February 2017).

31. Raij, B.; Cantarella, H.; Guaggio, J.A.; Furlani, A.M.C. Recomendações De Adubação E Calagem Para O Estado De São Paulo, 1st ed.; Instituto Agronômico and Fundacão IAC: Campinas, Brazil, 1997; pp. 6-13.

32. Vermote, E.F.; Tanre, D.; Deulze, J.L.; Herman, M.; Morcrette, J.J. Second Simulation of the Satellite Signal in the Solar Spectrum, 6S: An overview. IEEE Trans. Geosci. Remote 1997, 35, 675-686. [CrossRef]

33. Carlotto, M.J. Reducing the effects of space-varying, wavelength-dependent scattering in multispectral imagery. Int. J. Remote Sens. 1999, 20, 3333-3344. [CrossRef]

34. Neter, J.; Wasserman, W.; Kutner, M.H. Applied Linear Statistical Methods, 5th ed.; Irwin Professional Publishing: Chicago, IL, USA, 1985; pp. 50-78. 
35. Franco, H.C.J.; Pimenta, M.T.B.; Carvalho, J.L.N.; Magalhães, P.S.G.; Rossell, C.E.V.; Braunbeck, O.A.; Vitti, A.C.; Kolln, O.T.; Neto, J.R. Assessment of sugarcane trash for agronomic and energy purposes in Brazil. Sci. Agric. 2013, 70, 305-312. [CrossRef]

36. Trivelin, P.C.O.; Franco, H.C.J.; Otto, R.; Ferreira, D.A.; Vitti, A.C.; Fortes, C.; Faroni, C.E.; Oliveira, E.C.A.; Cantarella, H. Impact of sugarcane trash on fertilizer requirements for São Paulo, Brazil. Sci. Agric. 2013, 70, 345-352. [CrossRef]

37. Rosolem, C.A.; Calonego, J.C.; Foloni, J.S.S. Lixiviação de potássio da palha de espécies de cobertura de solo de acordo com a quantidade de chuva aplicada. Rev. Bras. Cienc. Sol. 2003, 27, 355-362. [CrossRef]

38. Endres, L.; Cruz, S.J.S.; Vilela, R.D.; Santos, J.M.; Barbosa, G.V.S.; Silva, J.A.C. Foliar applications of calcium reduce and delay sugarcane flowering. Bioenerg. Res. 2016, 9, 98-108. [CrossRef]

39. Vitti, G.; Luz, P.; Otto, R. Agrícola Ouro Verde, 10th ed.; Lençóis Paulista: Lencóis Paulista, Brazil, 2008; pp. 1-19.

40. Campos, M.; Antonangelo, J.A.; Alleoni, L.R.F. Phosphorus sorption index in humid tropical soils. Soil Tillage Res. 2016, 156, 110-118. [CrossRef]

41. Damon, P.M.; Bowden, B.; Rose, T.; Rengel, Z. Crop residue contributions to phosphorus pools in agricultural soils: A review. Soil Biol. Biochem. 2014, 74, 127-137. [CrossRef]

42. Pavinato, P.S.; Rosolem, C.A. Disponibilidade de nutrientes no solo—Decomposição e liberação de compostos orgânicos de resíduos vegetais. Rev. Bras. Cienc. Sol. 2008, 32, 911-920. [CrossRef]

43. Leite, J.M.; Ciampitti, I.A.; Mariano, E.; Vieira-Megda, M.X.; Trivelin, P.C. Nutrient, partitioning and stoichiometry in unburnt sugarcane ratoon at varying yield levels. Front. Plant Sci. 2016, 7, 1-14. [CrossRef] [PubMed]

44. Paul, G.C.; Bokhtiar, S.M.; Rehman, H.; Kabiraj, R.C.; Rahman, A.B.M.M. Efficacies of some organic fertilizers on sustainable sugarcane production in old Himalayan piedmont plain soil of Bangladesh. Pak. Sugar J. 2005, 20, 2-5.

45. Dotaniya, M.L.; Datta, S.C.; Biswas, D.R.; Dotaniya, C.K.; Meena, B.L.; Rajendiran, S.; Regar, K.L.; Lata, M. Use of sugarcane industrial by-products for improving sugarcane productivity and soil health. Int. J. Recycl. Org. Waste Agric. 2016, 5, 185-194. [CrossRef]

46. Aquino, G.S.; Medina, C.C.; Costa, D.C.; Shahaba, M.; Santiago, A.D. Sugarcane straw management and its impact on production and development of ratoons. Ind. Crops Prod. 2017, 102, 58-64. [CrossRef]

47. Singh, S.N.; Singh, A.K.; Malik, J.P.S.; Kumar, R.; Sharma, M.L. Cultural-practice packages and trash management effects on sugarcane ratoons under sub-tropical climatic conditions of India. J. Agric. Sci. 2012, 150, 237-247. [CrossRef]

48. Castioni, G.A.; Cherubin, M.R.; Menandro, L.M.S.; Sanches, G.M.; de Oliveira Bordonal, R.; Barbosa, L.C.; Carvalho, J.L.N. Soil physical quality response to sugarcane straw removal in Brazil: A multi-approach assessment. Soil Tillage Res. 2018, 184, 301-309. [CrossRef]

49. Carvalho, J.L.; Hudiburg, T.W.; Franco, H.C.; DeLucia, E.H. Contribution of above-and belowground bioenergy crop residues to soil carbon. Glob. Chang. Biol. Bioenerg. 2017, 9, 1333-1343. [CrossRef]

50. Oliveira, D.M.; Williams, S.; Cerri, C.E.; Paustian, K. Predicting soil C changes over sugarcane expansion in Brazil using the DayCent model. Glob. Chang. Biol. Bioenerg. 2017, 9, 1436-1446. [CrossRef]

51. Pitombo, L.M.; Cantarella, H.; Packer, A.P.C.; Ramos, N.P.; do Carmo, J.B. Straw preservation reduced total N2O emissions from a sugarcane field. Soil Use Manag. 2017, 33, 583-594. [CrossRef]

52. Vasconcelos, A.L.S.; Cherubin, M.R.; Feigl, B.J.; Cerri, C.E.; Gmach, M.R.; Siqueira-Neto, M. Greenhouse gas emission responses to sugarcane straw removal. Biomass Bioenergy 2018, 113, 15-21. [CrossRef]

53. Tavares, R.L.M.; Spokas, K.; Hall, K.; Colosky, E.; Souza, Z.M.D.; Scala, N.L. Sugarcane residue management impact soil greenhouse gas. Ciênc. Agrotec. 2018, 42, 195-203. [CrossRef]

54. da Silva, J. Sistemas de manejo da palhada influenciam acúmulo de biomassa e produtividade da cana-de-açúcar (var. RB855453). Act. Sci. Agron. 2010, 32, 345-350. [CrossRef]

55. Aquino, G.S.; de Conti Medina, C.; Junior, A.D.O.M.; Pasini, A.; Brito, O.R.; Cunha, A.C.B.; Almeida, L.F. Impact of harvesting with burning and management of straw on the industrial quality and productivity of sugarcane. Afr. J. Agric. Res. 2016, 11, 2462-2468. [CrossRef]

56. Aquino, G.S.; de Conti Medina, C.; Silvestre, D.A.; Gomes, E.C.; Benitez, A.C.; Cunha, D.A.O.K.; Santiago, A.D. Straw removal of sugarcane from soil and its impacts on yield and industrial quality ratoons. Sci. Agric. 2018, 75, 526-529. [CrossRef] 
57. Wang, Q.; Tenhunen, J.; Dinh, N.Q.; Reichstein, M.; Vesala, T.; Keronen, P. Similarities in ground- and satellite-based NDVI time series and their relationship to physiological activity of a scots pine forest in finland. Remote Sens. Environ. 2004, 93, 225-237. [CrossRef]

58. Balzarolo, M.; Anderson, K.; Nichol, C.; Rossini, M.; Vescovo, L.; Arriga, N.; Wohlfahrt, G.; Calvet, J.C.; Carrara, A.; Cerasoli, S.; et al. Ground-based optical measurements at european flux sites: A review of methods, instruments and current controversies. Sensors 2011, 11, 7954-7981. [CrossRef] [PubMed]

59. Genc, L.; Turhan, H.; Asar, B.; Smith, S.E. Comparison of spectral indices from QUICKBIRD and ground based hyper-spectral data for winter wheat. World Appl. Sci. J. 2009, 7, 756-762. [CrossRef]

60. Caturegli, L.; Casucci, M.; Lulli, F.; Grossi, N.; Gaetani, M.; Magni, S.; Bonari, E.; Volterrani, M. GeoEye-1 satellite versus ground-based multispectral data for estimating nitrogen status of turfgrasses. Int. J. Remote Sens. 2015, 36, 2238-2251. [CrossRef]

61. Bu, H.; Sharma, L.K.; Denton, A.; Franzen, D.W. Comparison of Satellite Imagery and Ground-Based Active Optical Sensors as Yield Predictors in Sugar Beet, Spring Wheat, Corn, and Sunflower. Agron. J. 2017, 109, 299-308. [CrossRef]

62. Morel, J.; Bégué, A.; Todoroff, P.; Martiné, J.F.; Lebourgeois, V.; Petit, M. Coupling a sugarcane crop model with the remotely sensed time series of fIPAR to optimise the yield estimation. Eur. J. Agron. 2014, 61, 60-68. [CrossRef]

63. Bégué, A.; Lebourgeois, V.; Bappel, E.; Todoroff, P.; Pellegrino, A.; Baillarin, F.; Siegmund, B. Spatio-temporal variability of sugarcane fields and recommendations for yield forecast using NDVI. J. Remote Sens. 2010, 31, 5391-5407. [CrossRef]

64. Jarrell, W.M.; Beverly, R.B. The dilution effect in plant nutrition studies. Adv. Agron. 1981, 34, $197-224$. [CrossRef]

65. Muchovej, R.M.; Newman, P.R.; Luo, Y. Sugarcane leaf nutrient concentrations: With or without midrib tissue. J. Plant. Nutr. 2005, 28, 1271-1286. [CrossRef]

66. Al-Abbas, A.H.; Barr, R.; Hall, J.D.; Crane, F.L.; Baumgardner, M.F. Spectra of normal and nutrient-deficient maize leaves. Agron. J. 1974, 66, 16-20. [CrossRef]

67. Raper, T.B.; Varco, J.J.; Hubbard, K.J. Canopy-Based normalized difference vegetation index sensors for monitoring cotton nitrogen status. Agron. J. 2013, 105, 1345-1354. [CrossRef]

68. Fernandes, J.L.; Ebecken, N.F.F.; Esquerdo, J.C.D.N. Sugarcane yield prediction in Brazil using NDVI time series and neural networks ensemble. ISPRS J. Photogramm. Remote Sens. 2017, 38, 4631-4644. [CrossRef] 